\title{
ANALISIS FAKTOR-FAKTOR YANG MEMPENGARUHI PEMBELIAN RUMAH DI KOTA MADIUN
}

\author{
Yopie Diondy Kurniawan \\ Politeknik Negeri Madiun \\ Yopie86@pnm.ac.id
}

\begin{abstract}
This study aims to analyze what factors influence the purchase of houses in the city of Madiun. The sample in this study amounted to 119 residents of the city of Madiun. The sampling technique in this study was conducted by insidential sampling method. The independent variables in this study are location, social environment, price, and community income while the dependent variable in this study is the purchase decision.The analysis in this study uses multiple linear regression which is done by testing classical assumptions first. The results showed that the price and environment had a positive and significant effect on the decision to buy a house in the city of Madiun, while the salary variable and location had a negative and insignificant effect on the purchase of a house in the city of Madiun.
\end{abstract}

Keywords: House Purchase, Price and Environment

\begin{abstract}
ABSTRAK
Penelitian ini bertujuan untuk menganalisis faktor apa saja yang mempengaruhi pembelian rumah di Kota Madiun. Sampel pada penelitian ini berjumlah 119 warga masyarakat Kota Madiun. Teknik pengambilan sampel pada penelitian ini dilakukan secara metode Sampling insidential. Variabel independen pada penelitian ini adalah lokasi, lingkungan sosial, harga, dan pendapatan masyarakat sedangkan variabel dependen pada penelitian ini adalah keputusan pembelian. Analisis pada penelitian ini menggunakan regresi linier berganda yang dilakukan pengujian asumsi klasik terlebih dahulu. Hasil penelitian menunjukkan bahwa Harga dan lingkungan berpengaruh positif dan signifikan terhadap keputusan pembelian rumah di Kota Madiun, sedangkan Variable gaji dan lokasi berpengaruh negative dan tidak signifikan terhadap pembelian rumah di Kota Madiun.
\end{abstract}

Kata Kunci: Pembelian rumah, Harga, Lingkungan

\section{PENDAHULUAN}

Setiap tahunnya terjadi peningkatan jumlah penduduk yang cukup tinggi sehingga berdampak atas tingginya permintaan hunian. Pertumbuhan penduduk tidak diimbangi dengan banyaknya rumah yang dibangun pengembang dikarenakan terbatasnya 
kemampuan penyediaan hunian oleh masyarakat, dunia usaha maupun pemerintah. Pada tahun 2016 kementerian PUPR dan Badan Pusat Statistik merilis data dimana kebutuhan perumahan mencapai 11,6 juta unit rumah dan meningkat setiap tahunnya. Kemampuan pembangunan perumahan yang terbatas dan masih berkembangnya berbagai orientasi kebutuhan masyarakat, menjadikan masalah pembangunan perumahan dan permukiman menjadi sangat penting.

Kota Madiun pada tahun 2016 berpenduduk sebesar 175.607 Jiwa dengan jumlah rumah tangga sebesar 69.377 KK. Dari data yang ada maka kita berasumsi setiap KK membutuhkan satu unit rumah sehingga idealnya kota madiun dibutuhkan unit rumah sebanyak 70.000 unit rumah. Tetapi dari data yang dikumpulkan jumlah unit rumah yang ada di Kota Madiun hanyalah sebesar 54.000 unit dengan berbagai macam tipe yang tersebar di berbagai tempat. Maka kebutuhan untuk rumah di Kota Madiun masih besar yaitu sebanyak 16.000 Unit rumah.

Investasi usaha pengembangan perumahan memiliki banyak aspek dan saling berhubungan, antara lain aspek : teknis dan nonteknis, ekonomi, sumber dana, peraturan-peraturan /perijinan, penjualan,dan masalah tanah itu sendiri. Perumahan adalah gedung yang dibangun oleh manusia di atas tanah yang sifatnya tidak dapat berpindah namun memiliki nilai ekonomi yang dapat dikuasai (Atkinson et al., 1974). Karekteristik investasi pembangunan perumahan memiliki dua kategori yaitu kategori ekonomi dan kategori fisik (Fillmore, 1991). Jangka panjang harga tanah pada lahan tersebut semakin meningkat nilainya. Karekteristik fisik tanah bersifat unique artinya bersifat tetap dimana posisi tanah satu dengan lainnya tidak dapat dipindahkan.

Data diatas peluang pembangunan rumah di kota madiun masih cukup besar untuk dikembangkan. Hal ini didukung dari data pemerintah Kota Madiun dimana semakin membaiknya kondisi ekonomi daerah dan meningkatnya pendapatan masyarakat. Hal ini didukung berkembang berbagai sektor usaha di kota madiun sehingga dapat sangat membantu pengembang menjalankan bisnis perumahannya. Kota Madiun terdapat 40 perusahaan yang bergerak di bidang property dan pembangunan perumahan baik rumah sederhana maupun mewah.

Di lingkungan pengembang masih ada ketika membangun lingkungan perumahan dan permukiman yang kurang berorientasi terhadap kepentingan konsumen dan hanya 
focus pada profit dan kejar target memenuhi kebutuhan rumah masyarakat. Aspek aspek berhubungan dengan pemilihan lokasi perumahan kurang diperhatikan seperti aspek harga, fasilitas, aksesbilitas ke pusat kota dan tempat penting lainnya serta kondisi lingkungannya.

Faktor lokasi salah satu faktor terkuat mempengaruhi nilai property. Dua buah property mempunyai bentuk dan fisik yang sama tetapi berlokasi yang berbeda, nilainya akan berbeda pula. Terdapat pendapat yang mengatakan faktor yang menentukan nilai property adalah lokasi, lokasi, dan lokasi sehingga menunjukkan pentingnya faktor lokasi menentukan nilai suatu property.

Kondisi lingkungan yang terkait dengan spesifikasi lingkungan perkotaan di satu sisi dan spesifikasi lingkungan kedesaan di sisi lain (J. S. Yunus, 2001). Spesifikasi lingkungan perkotaan berasosiasi secara spasial dengan berbagai fasilitas kehidupan dan kegiatan, sementara itu spesifikasi lingkungan pedesaan berasosiasi secara keruangan dengan kenyamana atmosfir untuk bertempat tinggal maupun menyelenggarkan kehidupan atau melaksanakan kegiatan dalam artian suhu, social, ekonomi, maupun budaya dan pemandangan alam (H. S. Yunus, 2008).

Pengamatan penulis pada perumahan yang dibangun di Kota Madiun ada yang lambat berkembang yang ditandai tingkat permintaan yang sangat rendah dari konsumen. Rumah yang dibeli tetapi tidak dihuni berakibat menambah luas tanah yang tidak digunakan secara efektif dan produktif. Dari sisi pengembang untuk rumah rumah yang terjual tetapi tidak dihuni tidaklah merugikan. Apalagi pada lokasi yang digunakan untuk membangun perumahan ternyata minat konsumen rendah. Akhirnya masalah pemenuhan tempat tinggal di Kota Madiun berjalan lambat. Dari hal tersebut penulis ingin meneliti faktor faktor yang mempengaruhi pembelian di Kota Madiun. Sehingga dari faktor faktor tersebut dapat diketahui bagaimana respon masyarakat dalam membeli rumah.

\section{LANDASAN TEORI}

Undang-Undang Nomor 4 Tahun 1992 Tentang Perumahan dan Permukiman, perumahan diartikan sebagai kelompok rumah yang berfungsi sebagai lingkungan tempat tinggal atau lingkungan hunian yang dilengkapi dengan sarana dan prasarana. 
Fisik perumahan merupakan lingkungan yang terdapat kumpulan unit-unit rumah tinggal dan terjadinya interaksi sosial antara penghuninya perumahan dan dalam perumahan tersebut dilengkapi prasarana sosial, ekonomi, budaya, dan pelayanan bagian dari subsistem kota secara keseluruhan. Dalam Lingkungan tersebut biasanya mempunyai aturan-aturan, kebiasaan-kebiasaan serta sistem nilai yang berlaku bagi warganya.

Pengertian perumahan dapat diartikan dengan pembangunan sejumlah rumah yang dibangun oleh instansi baik pemerintah atau swasta dan mempunyai desain unit rumah yang sama atau hampir sama. Jumlah rumah dan kelompok perumahan ini tidaklah tentu, ada yang hanya berisi dua atau tiga rumah ada yang bahkan mencapai ratusan rumah. Bentuknya pun tidak terbatas hanya pada bangunan satu lantai saja, yang berderet secara horizontal, melainkan dapat juga merupakan bangunan bertingkat yaitu merupakan rumah susun

\section{Aspek-aspek Perencanaan Perumahan}

Membuat perencanaan perumahan yang dapat menjawab tuntutan pembangunan perumahan dan permukiman sangat perlu dipertimbangkan sangat matang terhadap aspek-aspek perencanaannya. Memperhatikan aspek perencanaan pembangunannya, diharapkan baik arah maupun laju pembangunan perumahan dapat mencapai pada suatu kondisi jumlah dan kualitasnya sesuai dengan tuntutan, keinginan dan kebutuhan masyarakat. Aspek-aspek yang digunakan perencanaan pembangunan perumahan antara la:

\section{Lingkungan}

Hal yang harus dipertimbangkan perencanaan perumahan adalah adanya manajemen lingkungan yang terukur secara baik dan terarah. Lingkungan perumahan aspek yang sangat menentukan dan keberadaannya sehingga hal ini tidak dapat diabaikan/diacuhkan oleh pihak pengembang. Baik buruknya kondisi lingkungan akan berdampak terhadap kualitas penghuni perumahan. Pertimbangan faktor lingkungan pada saat perencanaan perumahan mutlak diperlukan karena hakekatnya pada proses terbentuknya lingkungan suatu perumahan terdapat akumulasi atau keseluruhan unitunit rumah yang akan menjadi pembentuk suatu perumahan tersebut. Diperlukan perencanaannya terhadap lingkungan perumahan tersebut berkaitan secara mikro 
(perencanaan secara detail terhadap unit-unit rumah) hingga makro (perencanaan dan pencermatan terhadap lingkungan dimana perumahan tersebut berada).

\section{Daya Beli (Affortability)}

Perencanaan bangunan digunakan untuk mendukung tercapainya tujuan pembangunan yang telah dicanangkan. Dalam perencanaan perumahan dipikirkan bagaimana kesesuaian antara ukuran bangunan, kebutuhan ruang, konstruksi bangunan, himgga bahan bangunan yang digunakan sehingg dapat terjangkau pelayanannya. Perlu diantisipasi pada kemampuan rata-rata (kemampuan daya beli) masyarakat yang berbeda antar wilayah. Faktor yang mempengaruhi daya beli masyarakat antara lain :

a) Pendapatan per kapita sebagian besar masyarakat yang masih rendah (di bawah standar) ;

b) Tingkat pendidikan pada masyarakat, terutama di daerah pedesaan yang masih relatif rendah;

c) Pembangunan yang belum merata antar daerah sehingga memicu timbulnya kesenjangan sosial dan ekonomi ;

d) Situasi politik dan keamanan negara yang cenderung tidak stabil sehingga mempengaruhi minat dan daya beli masyarakat untuk berinvestasi dan mengembangkan modal ;

e) Inflasi yang tinggi yang menyebabkan naiknya harga bahan bangunan yang berdampak dengan melambungnya harga rumah.

\section{Kelembagaan}

Keberhasilan pembangunan perumahan pada wilayah di perkotaan maupun di pedesaan, terdapat peran dari pemerintah yang merupakan pihak yang berkewajiban mengarahkan, membimbing, serta menciptakan suasana yang kondusif. Masyarakat sebagai pelaku utama pembangunan memegang peran penting setiap program pembangunan yang dijalankan. Dikaji lebih jauh unsur pelaku usaha pembangunan perumahan terdapat peran swasta sebagai pihak pengembang (kontraktor) yang menentukan arah dan laju pembangunan menuju masyarakat yang adil dan sejahtera dengan tercukupinya segala kebutuhan, termasuk kebutuhan perumahan. 


\section{METODE PENELITIAN}

Data pada penelitian ini didapat dari menyebarkan kuisioner ke masyarakat. Terdapat 107 kuisioner yang diisi oleh masyarakat Kota Madiun. Kemudian teknik pengambilan sampel penelitian menggunakan metode Sampling insidential. Pengambilan sampel berdasarkan kebetulan, yaitu siapa saja yang secara kebetulan/insidental bertemu dengan peneliti di awal digunakan sebagai sampel, tetapi dengan syarat orang yang ditemui sesuai sebagai sumber data yang berdomisili di Kota Madiun. Metode yang digunakan menganalisis yaitu metode Analisis Regresi linier berganda yang di olah menggunakan aplikasi spss. Penelitian menggunakan 1 variabel dependen serta 4 variabel independen dengan rincian sebagai berikut:

\section{Lokasi (X1)}

Lokasi berkaitan dengan aksesbilitas kemudahan dalam mencapai pusat kota dan tempat penting yang mendukung kegiatan sehari - hari dikarenakan untuk menunjang pergerakan penghuni rumah tersebut. Indicator dilihat dalam jarak tempuh.

\section{Harga (X2)}

Harga rumah pertimbangan utama konsumen. Harga rumah berkaitan dengan faktor fisik dan non fisik rumah. Semakin bagus dan kualitas rumah maka semakin tinggi harga rumah tersebut. Lokasi juga dapat sebagai penentu harga rumah.

3. Pendapatan Masyarakat (X3)

Tingkat pendapatan masyarakat berbeda - beda sedangkan biaya untuk membangun kontruksi relative tinggi. Penjualan rumah dapat didukung dengan system pembayaran yang dapat merangsang dan meningkatkan daya beli masyarakat dalam membeli rumah. Rumah yang di jual dengan harga terjangkau cenderung akan diminati oleh konsumen.

\section{Lingkungan (X4)}

Fungsi interaksi sosial dibutuhkan ruang untuk berinteraksi sosial, hubungan formal maupun informal melalui keberadaan ruang fisik dan organisasi social antar penghuni perumahan. Dimana orang muda, orang tua, orang yang belum 
berkeluarga, serta anak-anak, melalui penyediaan sarana, rekreasi, hiburan, pendidikan dan ruang terbuka.

\section{Keputusan Pembelian (Y)}

Keputusan pembelian apakah konsumen akan membeli rumah di suatu wilayah perumahan di suatu kota. Keputusan pembelian dipengaruhi berbagai macam hal. Pada penelitian kali faktor konsumen atau masyarakat meliputi faktor harga, lingkungan, jarak ke pusat kota maupun tingkat pendapatan warga

\section{Analisis Regresi}

Analisis regresi merupakan metode yang sangat popular dalam mencari hubungan antara 2 variabel atau lebih. Variabel yang dikomputasi dikelompokkan menjadi variable dependen yang biasanya dinotasikan dengan huruf Y dan variable independen yang biasanya dinotasikan dengan huruf $\mathrm{X}$. Variable dependen harus sama dengan 1 untuk analisis regresi, sebab dalam analisis ini kita akan mencari hanya satu nilai variable berdasarkan nilai-nilai variable independen yang jumlahnya bias lebih dari 1

Variabel dependen yang selanjutnya dinotasikan Y juga dikenal sebagai variable tak bebas, tergantung, respon ataupun outcome, sedangkan variable independen yang dinotasikan sebagai $\mathrm{X}$ dikenal sebagai variablel bebas, tak tergantung atau prediktor. Secara umum model regresi linier dinyatakan pada persamaan di bawah (Draper \& H, 1981).

$$
y=\beta_{0}+\beta_{1} x_{1}+\beta_{2} x_{2}+\ldots+\beta_{p} x_{p}
$$

\section{PEMBAHASAN}

Dalam gambaran umum karakteristik responden ini akan disajikan data yang diperoleh dari penelitian yang telah dilakukan. Pengumpulan data ini dilakukan dengan cara penyebaran kuesioner kepada 107 responden secara acak, uraian karakteristik responden adalah sebagai berikut. Kemudian sebanyak $81 \%$ telah menikah dan sebanyak 19\% belum menikah. 107 responden pada sebanyak $45 \%$ yang paling banyak berpendidikan sarjana, diikuti berpendidikan SMA sebanyak 23\% kemudian pascasarjan 
sebanyak 19\%. Responden pada Kota Madiun sebanyak 25 responden bekerja sebagai /TNI/POLRI hal ini dikarenakan di daerah Kota Madiun terdapat 2 homebase TNI yaitu Markas TNI 501 dan lanud iswahyudi.Sedangkan pada responden paling banyak kedua bekerja sebagai PNS dan Pegawai BUMN yaitu masing-masing sebanyak 17 responden. Hal ini juga dikarenakan Kota Madiun merupakan pusat dari industry kereta api Indonesia yaitu PT INKA sedangkan tempat ketiga yaitu pensiunan sebanyak 15 responden dimana hal ini sesuai salah satu julukan Kota Madiun yaitu kota pensiunan dimana banyak pensiunan di Kota Madiun.

Pada Obyek penelitian ini adalah analisis faktor-faktor yang mempengaruhi pembelian rumah di Kota Madiun menggunakan model regresi dilihat dari 4 pengaruh yaitu: lokasi, lingkungan sosial, harga, dan pendapatan masyarakat. Kemudian dilakukanlah pengambilan sampel data yang didapat dari survey di masyarakat Madiun di mana di ambil sampel pendahuluan sebanyak 25 orang untuk mengetahui uji validitas dan reliabilitas dari survey ini. Dari uji KMO dan Bartlet didapatkan hasil sebagai berikut :

Tabel 1 Uji KMO Dan Bartlet

\begin{tabular}{|c|l|l|c|}
\hline \multirow{2}{*}{$\begin{array}{c}\text { Kaiser-Meyer-Olkin } \\
\begin{array}{c}\text { Measure of Sampling } \\
\text { Adequacy. }\end{array}\end{array}$} & $\begin{array}{l}|c| \\
\text { Approx. } \\
\text { Chi- } \\
\text { Square }\end{array}$ & & \\
\hline 0.575 & 143.44 & 66 & Dig. \\
\hline
\end{tabular}

Dari tabel 1 hasil uji KMO didapatkan hasil .575 dengan nilain signifikansi 0.00 dan dimana angka tersebut lebih dari 0,5 dan nilai signifikan lebih dari 0.05 , maka variable dan sampel bisa dianalisis dengan menggunakan analisis factor

Tabel 2 Rotated Componet Matrik

\begin{tabular}{|l|r|c|r|c|}
\hline & & \multicolumn{2}{|c|}{ Component } & \\
\cline { 2 - 5 } & 1 & 2 & 3 & 4 \\
\hline harga1 & 0.768 & & & \\
\hline harga2 & 0.738 & & & 0.507 \\
\hline harga3 & 0.79 & & & 0.479 \\
\hline lokasi1 & & 0.879 & & \\
\hline lokasi2 & & 0.813 & & \\
\hline
\end{tabular}




\begin{tabular}{|l|r|l|r|l|}
\hline lingkungan2 & -0.5 & & 0.613 & \\
\hline lingkungan4 & 0.336 & & 0.742 & \\
\hline lingkungan5 & & & 0.767 & \\
\hline lingkungan6 & & & 0.696 & \\
\hline keputusan2 & & & & 0.932 \\
\hline keputusan3 & 0.312 & 0.344 & & 0.719 \\
\hline keputusan4 & & & 0.37 & 0.793 \\
\hline
\end{tabular}

Sumber: SPSS

Dari hasil perhitungan $t$ uji tersebut terdapat beberapa nilai yang keluar dari kelompoknya yaitu variable lokasi 3, lingkungan 1, lingkungan 3 dan keputusan 1. Sehingga untuk variable ini dihilangkan dari data sehingga untuk variable lokasi tersisa 2, variable lingkungan tersisa 4 dan variable keputusan tersisa 3.

Tabel 3 Uji Reliabilitas

\begin{tabular}{|l|l|l|}
\hline \multicolumn{1}{|c|}{ Variabel } & $\begin{array}{c}\text { Koefisien } \\
\text { Reliabilitas }\end{array}$ & \multicolumn{1}{c|}{ Simpulan } \\
\hline $\begin{array}{l}\text { Variabel } \\
\text { Keputusan }\end{array}$ & 0,665 & Reliabel \\
\hline Variabel Harga & 0,792 & Reliabel \\
\hline Variabel Lokasi & 0,730 & Reliabel \\
\hline $\begin{array}{l}\text { Variabel } \\
\text { Lingkungan }\end{array}$ & 0,688 & Reliabel \\
\hline
\end{tabular}

Sumber: SPSS

Hasil uji reliabilitas menunjukkan setiap variable reliable karena memiliki koefisien lebih dari R tabel sebesar 0,3961. Kemudian di lanjutkan dengan melakukan pengujian normalitas data dengan menggunakan One Sample Kormogorov-Smirnov Test sebagai berikut:

Tabel 4 Uji Normalitas

\begin{tabular}{|l|l|l|}
\hline Keterangan & P-Value & Simpulan \\
\hline & & $\begin{array}{l}\text { Berdistribusi } \\
\text { Normal }\end{array}$ \\
Normalitas & 0.135 & Sumber: SPSS
\end{tabular}

Berdasarkan hasil uji normalitas tersebut dapat diketahui bahwa p-value lebih besar dari 0,05 yaitu sebesar 0,135 sehingga dapat disimpulkan bahwa semua data 
terdistribusi dengan normal. Kemudian dilanjutkan dengan menguji multikolinieritas yang digunakan untuk menguji apakah ada tidaknya hubungan antar variabel

\section{Tabel 5 Uji Multikolinieritas}

\begin{tabular}{|l|l|l|l|}
\hline \multicolumn{1}{|c|}{ Variabel } & Tolerance & VIF & \multicolumn{1}{|c|}{ Simpulan } \\
\hline $\begin{array}{l}\text { Variabel } \\
\text { Harga }\end{array}$ & 0,368 & 2.714 & $\begin{array}{l}\text { Bebas } \\
\text { Multikolinearitas }\end{array}$ \\
\hline $\begin{array}{l}\text { Variabel } \\
\text { Lokasi }\end{array}$ & 0,499 & 2.006 & $\begin{array}{l}\text { Bebas } \\
\text { Multikolinearitas }\end{array}$ \\
\hline $\begin{array}{l}\text { Variabel } \\
\text { Gaji }\end{array}$ & 0,791 & 1.264 & $\begin{array}{l}\text { Bebas } \\
\text { Multikolinearitas }\end{array}$ \\
\hline $\begin{array}{l}\text { Variabel } \\
\text { Lingkungan }\end{array}$ & 0,444 & 2.251 & $\begin{array}{l}\text { Bebas } \\
\text { Multikolinearitas }\end{array}$ \\
\hline \multicolumn{2}{|l}{ Sumbr: SPSS } & & \\
\hline
\end{tabular}

Sumber: SPSS

Berdasarkan dari tabel 5 tolerance value lebih dari 0,01 dan VIF kurang dari 10, maka dapat disimpulkan bahwa masing-masing variabel untuk pengujian keputusan pembelian rumah di Madiun tidak ada hubungan antar variabel atau terbebas dari multikolinearitas. Kemudian kita lakukan uji heterokedastisitas.

Tabel 6 Uji Heterokedastisitas

\begin{tabular}{|c|c|c|c|}
\hline Variabel & $\mathbf{t}$ & Sig. & Simpulan \\
\hline $\begin{array}{c}\text { Variabel } \\
\text { Keputusan }\end{array}$ & $-2,227$ & 0,094 & Bebas Heteroskedastisitas \\
\hline Variabel Harga & 1,503 & 0.136 & Bebas Heteroskedastisitas \\
\hline Variabel Lokasi & 0,681 & 0,497 & Bebas Heteroskedastisitas \\
\hline Variabel Gaji & $-1,795$ & 0,076 & Bebas Heteroskedastisitas \\
\hline $\begin{array}{c}\text { Variabel } \\
\text { Lingkungan }\end{array}$ & 1,047 & 0,297 & Bebas Heteroskedastisitas \\
\hline
\end{tabular}

Sumber: SPSS

Berdasarkan tabel 6 dari hasil uji tersebut menunjukkan bahwa tidak ada satupun variabel yang mengalami masalah heteroskedaktisitas karena semua variabel 
menunjukan nilai signifikansi lebih besar dari 0,05. Kemudian dilakukan perhitungan analisis regresi yang didapatkan hasil sebagai berikut :

Tabel 7. Hasil Analisis Regresi

\begin{tabular}{|l|c|c|c|}
\hline \multicolumn{1}{|c|}{ Variabel } & Koefisien & t hitung & Sig. \\
\hline $\begin{array}{l}\text { Variabel } \\
\text { Harga }\end{array}$ & 0.327 & 4,292 & 0,000 \\
\hline $\begin{array}{l}\text { Variabel } \\
\text { Lokasi }\end{array}$ & 0.255 & 1,777 & 0,079 \\
\hline $\begin{array}{l}\text { Variabel } \\
\text { Gaji }\end{array}$ & -0.29 & $-2,193$ & 0,031 \\
\hline $\begin{array}{l}\text { Variabel } \\
\text { Lingkungan }\end{array}$ & 0.31 & 3,835 & 0,000 \\
\hline & $.768^{\mathrm{a}}$ & & \\
\hline R & 0.618 & & \\
\hline R Square & 41.654 & Sig. & $.000^{\mathrm{b}}$ \\
\hline \multicolumn{1}{|c|}{ F } & & & \\
\hline
\end{tabular}

Sumber: SPSS

Berdasarkan hasil tabel 4.7, maka dapat diperoleh persamaan sebagai berikut: M L $=-2,003+0.327$ Harga +0.255 Lokasi -0.290 Gaji $+0,310$ Lingkungan $+\mathrm{e}$

Berdasarkan persamaan regresi berganda di atas dapat diinterpretasikan sebagai berikut:

1. Nilai konstanta sebesar -0,854, menunjukkan bahwa jika variabel Harga, Lokasi, Gaji, serta Lingkungan diasumsikan konstan atau sama dengan nol maka keputusan pembelian rumah yang dilakukan oleh warga Madiun akan menurun.

2. Koefisien regresi variabel Harga bernilai positif sebesar 0.327. Hasil ini menunjukkan bahwa semakin besar harga pada suatu rumah maka menaikkan nilai keputusan pembelian rumah warga Madiun.

3. Koefisien regresi variabel lokasi bernilai positif sebesar 0.255menunjukkan bahwa semakin bagus lokasi rumah maka menaikkan nilai keputusan pembelian rumah warga Madiun.

4. Koefisien regresi variabel gaji menunjukan nilai negatif sebesar -0.290 . Hasil tersebut menunjukkan bahwa semakin rendah gaji maka menurunkan nilai keputusan pembelian rumah warga Madiun. 
5. Koefisien regresi variabel lingkungan bernilai positif sebesar 0,310. Hasil tersebut menunjukkan bahwa semakin baik lingkungan perumahan maka menaikkan nilai keputusan pembelian rumah warga Madiun.

Berdasarkan tabel diatas dapat diketahui nilai $\mathrm{R}^{2}$ sebesar 0,618 dapat menerangkan bahwa keputusan pembelian rumah masyarakat Kota Madiun model sebesar 61,8\% dapat dijelaskan oleh variable harga, lokasi, gaji serta lingkungan. Sedangkan sisanya 38,2\% dijelaskan oleh variabel lain diluar model regresi. Berdasarkan pada tabel diatas diperoleh nilai sebesar 41,654 dengan tingkat signifikansi atau probabilitas $0,000<0,05$, maka regresi pada model penelitian ini adalah fit.

Data yang telah dianalisis, variable harga berpengaruh signifikan terhadap keputusan pembelian rumah di Madiun. Menunjukkan harga mempengaruhi masyarakat Kota Madiun melakukan pembelian rumah walaupun harga yang dijual rumah tersebut mahal, tidak mempengaruhi masyarakat Kota Madiun dalam membeli rumah. Terdapat hubungan positif antara spekulasi perumahan dan harga perumahan. Hal ini tergambarkan pada hubungan antara harga rumah dan spekulasi di pasar keuangan (Sá et al., 2014). Dengan adanya spekulasi merugikan masyarakat karena hal tersebut meningkatkan fluktuasi harga di pasar. Faktor lainnya yang terjadinya pertumbuhan yang signifikan indeks harga rumah selama satu dekade terakhir di Malaysia adalah adanya kenaikan harga minyak dunia serta pertumbuhan angkatan kerja negara sehingga terjadi hubungan positif terhadap keputusan pembelian (Le, 2015).

Berdasarkan data yang telah dianalisis diketahui bahwa variable lokasi hanya mempunyai pengaruh minim terhadap keputusan pembelian rumah di Madiun. Sehingga lokasi tidak mempengaruhi masyarakat dalam melakukan pembelian rumah (Mariadas et al., 2016). Lokasi perumahan berada ditengah kota dan adanya akses penting di kota yang sangat mudah ternyata tidak menjadikan masyarakat Kota Madiun membeli rumah tersebut. Lokasi tidak mempunyai pengaruh yang signifikan terhadap pembelian rumah (Caritas et al., 2017; Putri \& Jamal, 2014). Masyarakat lebih memilih lingkungan perumahan dalam penentuan pembelian rumah diikuti dengan harga rumah.

Berdasarkan data yang telah dianalisis diketahui bahwa variable gaji tidak mempunyai pengaruh terhadap keputusan pembelian rumah di Madiun. Besaran gaji tidak mempengaruhi masyarakat melakukan pembelian rumah di Kota Madiun. 
Walaupun harga rumah yang di jual mahal ternyata tidak mempengaruhi dalam membeli rumah. Pendapatan atau gaji tidak begitu mempengaruhi dalam keputusan pembelian rumah (Utami et al., 2015). Menurut peneliti harga rumah menjadi faktor yang paling signifikan dalam keputusan masyarakat membeli rumah.

Berdasarkan data dianalisis bahwa variable lingkungan mempunyai pengaruh terhadap keputusan pembelian rumah di Madiun. Lingkungan perumahan/rumah yang akan dibeli mempengaruhi orang dalam membeli rumah dimana semakin baik lingkungan rumah tersebut semakin tertarik lah masyarakat dalam membeli rumah. Kualitas lingkungan juga merupakan salah satu aspek terpenting dalam pengukuran terhadap faktor-faktor yang mempengaruhi harga rumah di Malaysia (Hilmi et al., 2016). Karakteristik demografi telah banyak dikutip sebagai penentu utama keputusan pembelian perumahan (Omagwa \& Aduda, 2015).

\section{SIMPULAN DAN SARAN}

Berdasarkan hasil analisis dan pembahasan yang telah dikemukakan sebelumnya, maka dapat ditarik kesimpulan bahwa harga dan lingkungan berpengaruh positif dan signifikan terhadap keputusan pembelian rumah di Kota Madiun. Hal ini dapat dijelaskan bahwa semakin bagus harga rumah yang ditawarkan maka masyarakat semakin tertarik dalam membeli rumah di Madiun. Kemudian untuk variable lingkungan juga menjadi penentu dimana masyarakat lebih memilih melihat lingkungan perumahan apakah sesuai dengan yang diinginkan. Variable gaji dan lokasi berpengaruh negative dan tidak signifikan terhadap pembelian rumah di Kota Madiun. Dimana variable gaji ternyata tidak mempengaruhi orang dalam membeli orang dalam membeli rumah. Kemudian untuk variable lokasi yang dimana menjadi penentu untuk membeli rumah ternyata tidak menjadi penentu di Kota Madiun. Hal ini dapat dilihat dari adanya perumahan dengan lokasi berada di tengah kota dan dekat dengan pusat kota banyak yang masih belum terjual. Penelitian selanjutnya disarankan untuk menggunakan data yang lebih besar demi mendapatkan model dan hasil yang lebih bagus

\section{DAFTAR PUSTAKA}

Atkinson, G., Pereye, \& H. (1974). In: Modern Real Estate Practice. Dow Jones-Irwin Inc. 
Caritas, Arma, A. I., Wisnuurti, \& Suharyanto, A. (2017). Faktor - Faktor Yang Mempengaruhi Tingkat Kepuasan Hunian Perumahan Bersubsidi di Kota Malang. Jurnal Rekayasa Sipil.

Draper, N. ., \& H, S. (1981). Applied Regression Analysis (Edisi II). JohnWiley \& Son, Inc.

Fillmore, G. (1991). In: Modern Real Estate. Real Estate Education Company.

Hilmi, M., Nawawi, A. H., \& Sipan, I. (2016). Review of Building, Locational, Neighbourhood Qualities Affecting House Prices in Malaysia. Procedia-Sosial Dan Behavioral Science.

Undang-undang Republik Indonesia Nomor 4 Tahun 1992 Tentang Perumahan dan Permukiman, (1992).

Le, T.-H. (2015). Do Soaring Global Oil Prices Heat Up The Housing Market? Evidence From Malaysia",Kiel Institute for the World Economy (IfW). Kiel Institute for the World Economy (IfW), .

Mariadas, Anthony, P., Hong, T. K., \& Sevanathan, M. (2016). An Exploratory Research on the Factor That Influencing Housing Pricce Among Youngster In Klang Valley, Malaysia. Journal Of Management Dan Applied Science.

Omagwa, J., \& Aduda, J. (2015). The Mediating Effect of Housing Search on The Relationship Between Demographics and Residential Housing Decision Among Apartment Household in Nairobi County,Kenya. Journal Advances in Management \& Applied Economics.

Putri, H., \& Jamal, A. (2014). Faktor - Faktor Yang Mempengaruhi Pemilihan Lokasi Perumahan di Kota Banda Aceh. Jurnal Ekonomi Dan Kebijakan Publik Indonesia.

Sá, F., Towbin, P., \& Wieladek, T. (2014). Capital Inflows, Financial Structure, and Housing Booms. Journal of The European Economic Association, 12 (2).

Utami, A. B., Hamid, F. Z., \& S, M. O. (2015). Pengaruh Harga, Pendapatan, dan Lokasi Terhadap Keputusan Pembelian Rumah Di D'Kranji Residence Tahap II Bekasi Barat. Politeknik Negeri Jakarta.

Yunus, H. S. (2008). Dinamika Wilayah Peri Urban; Determinan Masa Depan. Pustaka Pelajar.

Yunus, J. S. (2001). Perubahan Pemanfaatan Lahan di Daerah Pinggiran Kota Kasus di Pinggiran Kota Yogyakarta. Fakultas Geografi, Universitas Gadjah Mada. 